\section{Kữ Kamonu Eğitim Dergisi Kastamonu Education Journal}

Ocak 2019 Cilt:27 Sayı:1

kefdergi.kastamonu.edu.tr
Başvuru Tarihi/Received: 08.01.2018

Kabul Tarihi/Accepted: 11.05.2018

DOI: $10.24106 /$ kefdergi.2541

\title{
Müzik Eğitimi Öğrencilerinde Bireysel Çalgı Performansı Başarısının Psikolojik ve Kişisel Özelliklere Göre İ́celenmesi ${ }^{1}$
}

\section{Investigation of Individual Instrument Performance Achievement of Music Education Students by Personal and Psychological Characteristics}

\section{Öz}

\author{
Sadık YÖNDEM ${ }^{2}$, Zeynep Deniz YÖNDEM ${ }^{3}$, Seda EDEN ÜNLÜ4, Zekeriya NARTGÜN ${ }^{5}$
}

Araştırmada, müzik eğitimi öğrencilerinde; akademik güdülenme, kaygı, denetim odağı gibi psikolojik ve çalgı geçmişi, günlük çalışma süresi gibi kişisel özelliklerin bireysel çalgı performansı başarısını yordama gücünün ve ilişkisinin test edilmesi amaçlanmıştır. Araştırmaya 80 müzik öğrenci katılmışttr. Verilerinin toplanmasında; Akademik Güdülenme Ölçeği, Beck Kaygı Envanteri, Rotter İç-Dış Denetim Odağı Ölçeği ve Kişisel Bilgi Formu kullanılmıştır. Verilerin analizinde, Pearson korelasyon analizi ve aşamalı regresyon analizi teknikleri kullanılmıştır. Araştırmanın sonucunda, bireysel çalgı performansı başarısı, kaygı ile negatif, akademik güdülenme ve günlük çalışma süresi ile pozitif yönde ilişkili bulunmuştur. Kaygı ve akademik güdülenmenin bireysel çalgı performans başarısının anlamlı yordayıcıları olduğu sonucuna ulaşılmıştr. Çalgı geçmişi ve denetim odağı gibi değişkenlerle, bireysel çalgı performans başarısı arasındaki ilişkilerin anlamlı olmadığı saptanmıştır.

Anahtar Kelimeler: Müzik eğitimi, performans başarısı, akademik güdülenme, kaygı, denetim odağı.

\section{Abstract}

The study aims to test predictive power and relationship between musical instrument performance achievement and some psychological characteristics such as academic motivation, anxiety, and locus of control and some individual characteristics such as instrument background and daily practice time in music students. A total of 80 music students participated in the study. For the data collection; the Beck Anxiety Inventory, Academic Motivation Scale, Rotter Internal-External Locus of Control Scale and Personal Information Form were used. Pearson correlation tecnics and stepwise regression analysis were used for the analysis of the research data. The results of study showed that there were negative relation with anxiety and positive relation with academic motivation, and daily practice time with the instrument performance achievement.The regression analysis results showed that the individual instrument performance scores predicted by anxiety and academic motivation. However, it was found that the relations with the instrument backround and locus of control were not significant.

Keywords: Music education, performance achievement, academic motivation, anxiety, locus of control.

1. Bu çalışma Uluslararası 3. İpek Yolu Müzik Konferansında sözlü bildiri olarak sunulmuştur . 17-19 Temmuz 2017 Gazimağusa/KKTC

2. Bolu Abant İzzet Baysal Üniversitesi, Eğitim Fakültesi, Güzell Sanatlar Eğtimi Bölümü, Bolu, Türkiye; https://orcid.org/0000-0001-7838-6220

3. Bolu Abant İzzet Baysal Üniversitesi, Eğitim Fakültesi, Eğitim Bilimleri Bölümü, Bolu, Türkiye; https://orcid.org/0000-0002-9161-2760

4. Bolu Abant İzzet Baysal Üniversitesi, Eğitim Fakültesi, Güzell Sanatlar Eğtimi Bölümü, Bolu, Türkiye; https://orcid.org/0000-0002-3947-7442

5. Bolu Abant İzzet Baysal Üniversitesi, Eğitim Fakültesi, Eğitim Bilimleri Bölümü,, Bolu Türkiye; https://orcid.org/0000-00034006-372X

Atıf / Citation: Yöndem, S., Yöndem, Z.D., Eden Ünlü, S., \& Nartgün, Z. (2019). Müzik eğitimi öğrencilerinde bireysel çalgı performansı başarısının psikolojik ve kişisel özelliklere göre incelenmesi. Kastamonu Education Journal, 27(1), 299-307. doi:10.24106/kefdergi.2541 


\section{Extended Abstract}

\section{Purpose and Significance}

Individual instrument refers to an instrument which is selected by university music students and they focus on it more than other instruments, and it also effects all their professional career. Music students are expected to carry out performance-based activities such as examinations, concerts and recitals during their vocational training and to use them effectivly as a teaching tools while serving in schools as a music teacher after graduation.

In this scope, it is important for music students to reach higher level in their instrument performance achievement during the undergraduate education. So they expected to use their instument as a teaching tool effectively in various educational settings after graduation (Yöndem, 2016). Music students' instrument performances may depend on various personal or other variables such as their interest, motivation, practicing time, anxiety level, locus of control beliefs, and instrument backrounds. The study aims to test the relationship between some psychological characteristics such as motivation, anxiety, locus of control and some individual characteristics such as instrument backround and daily practice time, and the instrument performance achievement of music students. The question 'do the instrument backround, daily practice time, academic motivation, anxiety level and locus of control predict individual instrument performance achievement?' is tried to be answered.

\section{Method}

Relational screening method was used in this study. It is aimed to test the relationship between the variables of academic motivation, anxiety level, locus of control, the instrument backround, daily practice time, and the individual instrument performance achievement. Participants of the study consist of a total of 80 undergraduate music students at one of the state university in Turkey. The age range of the participants is 18-27 and the mean age is $\bar{X}=$ $20.86(\mathrm{~S}=1.83)$. The gender of the participants is 52 female and 28 male students; the class level is 24 students at the 1st grade, 28 students at the second grade, 8 students at the third grade and 20 at the fourth grade. The distribution of individual instrument types of the participants were; 24 violin, 15 guitar, 13 flute, 12 cello, 8 baglama, and 7 viola. The range of the individual instrument performance scores, which is the dependent variable of the research, varies between 36 and 100 in an hundred-based evaluation system. For the data collection, Beck Anxiety Inventory, Academic Motivation Scale, Rotter Internal-External Locus of Control Scale and Personal Information Form were used. Pearson correlation technique and stepwise regression analysis methods were used in the analysis of the research data. Prior to the regression analysis, the data were tested for regression hypothesis.

\section{Discussion and Conclusion}

It was found that there were negative correlation with anxiety and positive correlations with academic motivation and daily practice time between the individual instrument performance scores. Regression analysis results showed that variance (with the $17 \%$ rate) of the individual instrument performance score predicted by anxiety and motivation. However there were some relations between daily practice time and motivation, and locus of control and motivation, this variables not predict the individual instrument performance scores. The results of the present study showed that academic motivation was one of the good predictor of individual instrument performance achievement with similar the related literatüre resulst which indicating that motivation is a strong predictor of academic achievement and music performance achievement. While considering on variables related to motivations, there were some results that reported the personality types such as open to new experiences and outwardness which dominant personality characteristics of music students and generally for artistic professions may support academic motivation in music students.

In addition, it may be important to support instrument performance of music students with activities such as recital, concert, concert tour rather than just evaluating it in exams. In addition, research literature frequently emphasizes the relationship between self-efficacy beliefs; and motivation and achievement (Azar, 2010). In this respect, approaches of instructors that will positively influence motivation such as appreciating and approving successful students by using positive communication techniques can be listed among very important factors. The finding that the anxiety level is a significant predictor of the individual instrument performance achievement is in parallel with the performance anxiety results in music students which is frequently studied topic in the music literature. In this study, it is interesting that the variables such as daily practice time and locus of control are not significant predictors of instrument performance achievement, but they related with motivation. This results supported by some music performance literature results which they argued accepted the locus of control theory as one of the social cognitive motivational theory. However, there were some results that the internal or external locus of control, the belief on the validity of effort or chance factors are important features for instrument performence achievement. In this respect, it may be suggested to test the relationship between the locus of control and the instrument achivement by grouping internal-external locus of control in larger samplings in further studies. 


\section{Giriş}

Müzik eğitiminde, müzik alanında belirli bir düzeyde yeteneği olan ve belirli bir müzik dalını meslek olarak seçen bireylere; müziksel bilgi, beceri ve kültürün kazandırılması amaçlanmaktadır (Yağışan, Sünbül ve Yücelan, 2007). Ses eğitimi ve çalgı eğitimi müzik eğitiminin temel öğelerindendir. Bunlardan ses eğitiminde, sesleri doğru duyabilme ve kullanabilme becerisinin geliştirilmesi amaçlanmaktadır. Çalgı eğitiminde ise çalgıyı tekniğine uygun ve temiz seslerle çalma, müziğin dönemsel özeliklerini yansıtma ve topluluk içinde görev alma becerilerinin geliştirilmesi hedeflenmektedir.

Müzik eğitimi öğrencileri diğer çalgılara oranla bireysel çalgı eğitimine daha fazla yoğunlaşmakta ve çalgı tercihi tüm mesleki kariyerlerini etkilemektedir. Eğitimini aldıkları bireysel çalgı ile bir yandan mesleki eğitim süresince; sınav, konser ve resital gibi performansa dayalı etkinlikler sergilemeleri, diğer yandan hizmet sunacakları okullarda; okul çalgı toplulukları oluşturma, orkestra hazırlama ve yönetme gibi eğitsel görevler üstlenmeleri beklenmektedir (Yöndem, 2016). Bu nedenle bireysel çalgısını etkili kullanma becerisinin yeterli düzeyde gelişmiş olması hedeflenmektedir.

Müzik eğitiminde önemli bir yer tutan bireysel çalgı performansı başarısının, ilişkili olabileceği değişkenlerin belirlenmesi önemlidir. Çalgı performans başarı ya da başarısızlığının olası nedenleri, müzik eğitiminin ilgi duyulan araştırma konularındandır. Özellikle yurt dışında, müzik performansı sergileyen farklı yaş grubundan bireylerle yapılan çalışmalarda; bilişsel özellikler, müziğe yönelik tutum, seçilen çalgı türü, genel akademik başarı, güdülenme, fiziksel nitelikler ve sosyo ekonomik düzey gibi müzikle ilgili ya da ilgili olmayan bir takım özelliklerin müzik performans başarısı ile ilişkisi test edilmiştir (Sloboda, 2000; Klinedinst,1991). Cribb ve Gregory (1999) bireysel çalgı seçiminde kişilik özelliklerinin ve sosyal faktörlerin rolü olduğunu belirtmiştir. Bazı araştrmalarda ise sosyo-ekonomik düzey ile müzik performans başarısı arasında ilişki raporlaştrıımıştır (Klinedinst,1991). Sloboda (2000), müzik performansının altında yatan psikolojik özelliklerin karmaşıklığına ve çok boyutluluğuna dikkat çekmektedir. Güdülenme, benlik kavramı, denetim odağı, öz yeterlilik (Schmidt, 2005; Klinedinst,1991; McPherson ve McCormick, 2006) müzik performans başarısı ile ilişkili olduğu raporlaştrılan psikolojik özelliklerden bazıları olarak literatürde geçmektedir.

Müzik eğitimi alanında ülkemizde yapılan çalışmalar incelendiğinde, genel akademik başarının, öğrencilerin lisans eğitimi öncesinde mezun oldukları okul türlerine ve cinsiyete göre karşılaştııldığı çalışmalar bulunmaktadır. Bu çalışmalarda genel liseden mezun olanların güzel sanatlar lisesi mezunlarına göre daha başarılı olduğu (Kurtuldu ve Aksu, 2016) ya da mezun oldukları lise türüne göre farklılık olmadı̆̆ı (Aksu ve Çelenk, 2014), kızların erkeklere göre akademik başarılarının daha yüksek olduğu gibi bulgular raporlaştırılmıştır. Bir başka korelasyonel çalışmada müzik eğitimi öğrencilerinin lisans eğitimi akademik başarılarının, öğretmenlik mesleğine güdülenme düzeylerini çok az düzeyde etkilediği sonucuna ulaşılmıştır (Onuk, 2007). Özmenteş ve Özmenteş (2009)'in müzik eğitimi öğrencilerinin, çalgı çalışmaya yönelik tutumlarını inceledikleri çalışmada, 17-19 yaş grubundakilerin daha büyük yaş grubundakilere ve günlük çalgı çalışma süresi fazla olanların az olanlara göre daha olumlu tutum sergiledikleri, oysa cinsiyet ve bireysel çalgı türüne göre çalışma tutumlarının farklılık göstermediği bulunmuştur.

Akademik başarıyı ve bireysel çalgı performansı başarısını etkileyebilecek önemli değişkenlerden güdülenme, enerjinin performansı ortaya çıkarma sürecini ifade etmektedir (Bozanoğlu, 2004; Şahin ve Çakar, 2011). Güdülenme, genel olarak davranışı harekete geçiren, sürdüren ve yönlendiren bir süreç olarak geçmektedir (Slavin, 2012). Güdülenme bireyin kendini harekete geçirdiği merak, ilgi, başarma isteği gibi içsel ya da ödül, övgü, onaylanma gibi dışsal kaynaklı olabilmektedir (Demir ve Arı, 2013). Güdülenme düzeyi ve yoğunluğu bireyden bireye farklılık göstermekte ve başarıyı etkilemektedir. Asmus (1995, akt.Schmidt, 2005) güdülenmenin müzik başarısını önemli düzeyde etkilediğini belirtmiştir. Çalgı eğitiminde güdülenmenin önemini vurgulayan bazı kuramsal çalışmalar (Güleç, 2009; Orhan, 2010) bulunmaktadır. Özmenteş (2013)'in, motivasyon ve çalgı başarısı konusundaki araştırmasında, öğrencilerin anadal çalgı başarılarının; yetenek, çalışma ve kararlı bir kişiliğe sahip olma gibi değişkenlere bağlı olduğu raporlaştırılmıştır. Modırı (2012) ise, öğrencilerin piyano dersi motivasyonu ile kişilik özellikleri arasında ilişki olmadığı sonucuna ulaşmıştr.

Bireylerin başarı ya da başarısızlıklarına ilişkin yükleme stillerini ifade eden ve güdülenme teorilerinden biri olarak da geçen denetim odağı (Schmidt, 2005), bireysel çalgı performans başarısını etkileyebilecek özelliklerdendir. Buna göre karşılaştı̆ı olumlu ya da olumsuz durumları yetenek, çalışma, çaba gösterme gibi kendi kontrolündeki davranışlara yükleyenler içsel denetim odağı yönelimli, kendi kontrolü dışında şans, kader, kısmet ya da başka kimselerle ilişkilendirenler ise dışsal denetim odağı yönelimli olarak kabul edilmektedirler (Deryakulu, 2002; Slavin, 2012). Denetim odağı ile ilgili araştırmalar, içsel denetim odaklı bireylerin akademik yönden daha başarılı olduklarını, başarılı olmak için daha çok zaman ve çaba harcadıklarını, güdülenme düzeylerinin daha fazla olduğunu göstermektedir (Deryakulu, 2002; Dönmez,1985). Müzik eğitimi öğrencilerinin ve kızların daha çok içsel denetim odaklı olduklarına (Akbulut, 2006) yönelik 
araştırma bulguları bulunmaktadır. Yağışan, Sünbül ve Yücelan (2007) müzik eğitimi öğrencileri ile yaptıkları çalışmada, denetim odağının kendini algılama biçimini ifade eden benlik imgeleriyle ile ilişkili olduğunu bulmuşlardır.

Müzik eğitimi ve performans başarısı ile ilgili literatürde, performans kaygısı olarak da geçen çalgı performans kaygısının müzik eğitimi öğrencilerinde ve profesyonel müzisyenlerde yaygın olarak gözlendiği (Yöndem, 2012), sınav kaygısı ile çalgı başarısı arasında ilişki olduğu (Küçük, 2010, Nacakçı ve Dalkıran, 2011) bulguları bulunmaktadır.

Burada özetlenen literatür bulgularına dayanarak, bu çalışmada bireysel çalgı performans başarısının; çalgı geçmişi, günlük çalışma süresi, güdülenme, kaygı düzeyi, denetim odağı gibi değişkenlere göre test edilmesi amaçlanmıştr. İlgili literatürde birbirinden bağımsız olarak bu özellikler ele alınsa da hepsinin birlikte ele alındığı bir çalışmaya rastlanmamıştr. Araştırmanın bu bakımdan müzik eğitimi ve çalgı performansı literatürüne katkı sağlaması beklenmektedir.

Bu araştrrmada, müzik eğitimi öğrencilerinde; akademik güdülenme, kaygı düzeyi, denetim odağı ile çalgı geçmişi ve günlük çalışma süresi, bireysel çalgı performans başarısını yordamakta mıdır?' sorusuna yanıt aranmaktadır.

\section{Yöntem}

Araştırmada ilişkisel tarama yöntemi kullanılmıştır. Araştırmanın bağımlı değişkeni olan bireysel çalgı performans başarısını; akademik güdülenme, kaygı düzeyi ve denetim odağı ile bireysel çalgı geçmişi ve günlük çalışma süresinin yordama gücü bireysel çalgı performans başarısı ile ilişkilerinin test edilmesi amaçlanmıştır.

\section{Katilımcilar}

Araştırmanın katılımcıları, bir devlet üniversitesinin, Güzel Sanatlar Eğitimi Bölümü Müzik Eğitimi'nde öğrenim gören 80 lisans öğrencisinden oluşmaktadır. Araştırma katılımcılarının yaş aralığı 18-27 ve yaş ortalaması $\bar{X}=20.86$ (S= 1.83)'dir. Katılımcıların cinsiyet, sınıf düzeyi ve bireysel çalgı türüne göre dağılımı Tablo.1'de verilmiştir.

Araştırma katılımcılarının, araştırmada bağımlı değişken olarak alınan bireysel çalgı performans başarısı puan aralıkları yüzlük değerlendirme sisteminde, 36 ile 100 arasında değişim göstermektedir. Araştırmada bireysel çalgı performans başarısı üzerindeki etkisi test edilen bağımsız değişkenlerden, çalgı geçmişinin 1 yıl ile 15 yıl arasında değişim gösterdiği ve ağırlıklı olarak 5-8 yıllık bir çalgı geçmişi raporlaştııldığı gözlenmiştir. Bireysel çalgı günlük çalışma süresinin ise 30 dakika ile 3.30 saat arasında değişim gösterdiği belirlenmiştir.

Tablo 1. Araştırma katılımcılarının özellikleri $\quad(\mathrm{N}=80)$

\begin{tabular}{llcc}
\hline Katlımcı Özellikleri & & $\mathrm{f}$ & $\%$ \\
\hline \multirow{2}{*}{ Cinsiyet } & Kadın & 52 & 65 \\
& Erkek & 28 & 35 \\
\hline \multirow{3}{*}{ Sınıf Düzeyi } & 1. Sınıf & 24 & 30 \\
& 2. Sınıf & 28 & 35 \\
& 3. Sınıf & 8 & 10 \\
& 4. Sınıf & 20 & 25 \\
\hline \multirow{3}{*}{ Bireysel Çalgı Türü } & Keman & 24 & 30 \\
& Gitar & 15 & 19 \\
& Flüt & 13 & 16 \\
& Çello & 12 & 15 \\
& Bağlama & 9 & 11 \\
& Viyola & 7 & 9 \\
\hline
\end{tabular}

\section{Veri Toplama Araçları}

Araştırma verilerinin toplanmasında; Akademik Güdülenme Ölçeği, Beck Anksiyete Envanteri, Rotter İç-Dış Denetim Odağı Ölçeği ve Kişisel Bilgi Formu kullanılmıştır.

Akademik Güdülenme Ölçeği-AGÖ: Bozanoğlu (2004) tarafindan geliştirilen ölçek, 20 maddeden oluşmakta ve 5'li derecelendirme (1-Kesinlikle Uygun Değil, 5-Kesinlikle Uygun) ile yanıtlanmaktadır. Ölçekten alınabilecek en yüksek puan 100, en düşük puan 20'dir. Ölçekten alınan puanların yüksekliği akademik güdülenme düzeyinin yüksek olduğunu yansıtmaktadır. Ölçek daha çok tek faktörlü kullanıma uygun olmakla birlikte isteğe göre üç ayrı alt faktör (kendini aşma, bilgiyi kullanma ve keşif) olarak da puanlama yapılabilmektedir. Bu çalışmada ölçeğin toplam puanı dikkate alınmıştr. Ölçeğin uyarlama çalışması amacıyla yapılan faktör analizinde toplam varyansın \% 42.2'sini açıkladığı, madde 
analizinde her bir maddenin toplam puan ile korelasyonunun .43 ile .60 arasında olduğu ve başarı düzeyi yüksek ve düşük grupları anlamlı düzeyde ayırt edebildiği raporlaştrılmıştı. Güvenirlik çalışmasında ise test-tekrar test güvenilirliği .87, iç tutarlılık güvenirlik katsayısı ise .86 olarak raporlaştırılmıştır (Bozanoğlu, 2004).

Beck Anksiyete Envanteri-BAE: Ölçeğin Türkçe'ye uyarlama çalışması Ulusoy, Şahin ve Erkmen (1998, akt.Savaşır ve Şahin, 1997) tarafindan yapılmıştr. Toplam 21 maddeden oluşan 4'lü derecelendirme türü (0-Hiç, 3-Ciddi derecede) kendini değerlendirme ölçeğidir. Ölçekten alınabilecek puanlar 0 ile 63 arasında değişmektedir. Ölçeğin geçerlik çaıışması için, Sürekli-Durumluk Kaygı Ölçeği (STAI-T, STAI-S) ile ölçüt bağıntılı geçerlik çalışması yapılmış ve korelasyonu $r=.48$ ve $. r=50$ olarak raporlaştrılmıştı. Yapı geçerliği çalışmasında ise klinik gruplarla yapılan çalışmalarda kaygılı bireyleri başarılı bir şekilde ayırt edebildiği gözlenmiştir. Yine test tekrar test güvenirliği $r=.75$ ve $r=.67$; Cronbach Alfa iç tutarlılık katsayısı ise .92 olarak raporlaştrıımıştır ( Savaşır ve Şahin, 1997).

Rotter İç Dış Kontrol Odağı Ölçeği-RiDKOÖ: Dağ (1991 akt.Savaşır ve Şahin, 1997) tarafindan Türkçe'ye uyarlanan ölçek, toplam 29 maddeden oluşmakta ve (a) ya da (b) harfleriyle gösterilen yanıtlama seçenekleri bulunmaktadır. Ölçeği yanıtlayan kişiden kendisine uygun gelen cümleyi seçmesi ve işaretlemesi beklenmektedir. Puanlamasında ise dışsal denetime yönelik seçenekler 1 diğerleri 0 olarak puanlanarak toplam puan elde edilmektedir. Ölçekten alınacak puanlar 0 ile 23 arasında değişmekte ve alınan puanların yüksekliği dışsal denetimin daha fazla olduğunu yansıtmaktadır. Ölçeğin güvenirlik çalışmaları; iç tutarlıık (.77), iki yarım test (.65 ile.79 arası) ve test tekrar test (.49 ile .83 arası) yöntemleri ile test edilmiştir. Geçerlik çalışması için, faktör analizi yapılmış ve başka kontrol odağı ölçekleri ile yapılan ölçüt geçerliği çalışmalarında korelasyon katsayıları .25 ve .55 olarak raporlaştrılmıştır (Savaşır ve Şahin,1997). Ölçek temelde bireyin başarı ya da başarısızıklarını kendi kontrolündeki (çaba- çalışma) veya kontrolü dışındaki (şans-kader) etkenlerle açıklama tarzlarını belirlemeyi amaçlamaktadır.

Kişisel Bilgi Formu: Araştırma kapsamında hazırlanan kişisel bilgi formu ile; katılımcıların; cinsiyeti, sınıf düzeyi, bireysel çalgı türü, çalgı geçmişi ve günlük çalışma süresi hakkında bilgiler toplanmıştr. Kişisel bilgi formunda yer alan bilgiler katılımcıların kendi bildirimlerine dayalı olarak elde edilmiştir.

\section{Verilerin Toplanması}

Araştırma verileri, sınıflarda, toplu derslerin ardından, ilgili öğretim elemanının izni ve onayı ile toplam 86 katlımcıdan, gönüllülük esasına dayanarak toplanmıştr. Uygulamalar öncesinde verilerin toplanacağı üniversitenin etik kurulunun onayı alınmıştır. Katılımcılardan hatalı ve eksik anket dolduran 6 katılımcı ile ilgili veriler çıkarılarak toplam 80 katılımcıdan toplanan veriler ile analizler yapılmıştır.

\section{Verilerin Analizi}

Araştırma verilerinin analizinde Pearson Korelasyon tekniği ve Aşamalı Regresyon analizi yöntemleri kullanılmıştır. Regresyon analizi öncesinde veriler; sürekli değişken olması, normal dağılım ve çoklu bağlantının (multicolliniearty) bulunmaması yönünden test edilmiştir. Yapılan ön analizlerde test edilen modelin araştırma verileriyle uyumlu olduğu gözlenmiştir. Ayrıca araştırmanın bağımlı değişkeni olan bireysel çalgı performans başarısı puanının belirlenmesinde, öğrencilerin bilgisi dâhilinde, lisans öğrenimi süresince komisyon değerlendirmelerinden elde edilen bireysel çalgı puanlarının ortalaması dikkate alınmıştr. Katılımcıların bireysel çalgı performansı başarı puanı tek bir öğretim elemanı tarafindan değil, aynı bireysel çalgı grubu alanındaki komisyon tarafindan değerlendirildiği için, daha güvenilir ve geçerli olduğu varsayılmaktadiğer düzeyde başlıklar için metin kalın kullanılabilir. Sayılar kullanılmamalıdır.

\section{Bulgular}

Bu Araştırmada ele alınan değişkenlerin bireysel çalgı performans puanları ile ilişkisi tablo.1' de verilmiştir. Araştırmanın bağımlı değişkeni olan bireysel çalgı puanı ile bağımsı değişkenlerden; çalgı geçmişi, günlük çalışma süresi, akademik güdülenme, kaygı düzeyi ve denetim odağı arasında ilişkiler olduğu bulunmuştur. Ancak bireysel çalgı puanı ile çalgı başlama süresi ve denetim odağı arasındaki düşük ilişkilerin anlamlı olmadığı gözlenmiştir. Oysa bireysel çalgı puanı ile günlük çalışma süresi $r=.237 ; p=.035(p<.05)$ ve akademik güdülenme $r=.271 ; p=.015(p<.05)$ arasında anlamlı pozitif, kaygı düzeyi $r=-.351 ; p=.001(p<.005)$ arasında anlamlı negatif ilişkiler olduğu bulunmuştur. 
Tablo. 2 Bağımsız değişkenler ile bireysel çalgı puanı arasındaki Pearson Korelasyon Katsayıları ( $\mathrm{N}=80$ )

\begin{tabular}{|c|c|c|c|c|c|c|c|}
\hline Değişkenler & & $\begin{array}{c}\text { Bireysel Çalgı } \\
\text { Puanı }\end{array}$ & $\begin{array}{c}\text { Çalgı } \\
\text { Geçmişi }\end{array}$ & $\begin{array}{c}\text { Günlük } \\
\text { Çalışma Süresi }\end{array}$ & $\begin{array}{c}\text { Akademik } \\
\text { Güdülenme }\end{array}$ & Kaygı Düzeyi & Denetim Odağı \\
\hline \multirow{2}{*}{ Bireysel Çalgı Puanı } & $r$ & 1 & -.034 & $.237^{*}$ & $.271^{*}$ & $-.351 * *$ & .031 \\
\hline & $p$ & & .764 & .035 & .015 & .001 & .783 \\
\hline \multirow{2}{*}{ Çalgı başlama süresi } & r & & 1 & -.080 & -045 & .057 & .047 \\
\hline & $p$ & & & .483 & .695 & .613 & .680 \\
\hline \multirow{2}{*}{ Günlük çalışma süresi } & r & & & 1 & $.353^{* *}$ & -.148 & -.165 \\
\hline & $\mathrm{p}$ & & & & .001 & .189 & .143 \\
\hline \multirow{2}{*}{ Akademik Güdülenme } & r & & & & 1 & -.190 & $-.245^{*}$ \\
\hline & $p$ & & & & & .092 & .028 \\
\hline \multirow{2}{*}{ Kaygı Düzeyi } & r & & & & & 1 & .015 \\
\hline & $\mathrm{p}$ & & & & & & .892 \\
\hline Denetim Odağı & $r$ & & & & & & 1 \\
\hline
\end{tabular}

Bu bulgular doğrultusunda bireysel çalgı puanı ile anlamlı ilişkilerin gözlendiği değişkenler regresyon analizine dahil edilmiştir. Korelasyon analizlerinde bireysel çalgı puanı ile günlük çalışma süresi arasında düşükte olsa anlamlı bir ilişki $(r=.237 ; p=.035(p<.05)$ gözlenirken, regresyon analizi bu değişkeni nitelikli bir yordayıcı olarak kabul etmemiştir. Bu nedenle regresyon analizine kaygı düzeyi ve akademik güdülenme değişkenleri dahil edilmiştir. Regresyon analizi öncesinde modelin uygunluğuna ilişkin ANOVA testi yapılmış, modelin anlamlı olduğu $(F=7.703 ; p<.05)$ ve değişkenler arası çoklu bağlantı sorunu olmadığı test edilmiştir.

Akademik güdülenme ve kaygı değişkenlerinin bireysel çalgı başarı puanını yordama gücünü test etmek amacıyla uygulanan aşamalı (stepwise) regresyon analizi sonuçları tablo. 3 'de verilmiştir.

Tablo. 3. Bireysel çalgı performans başarısını yordayan değişkenlere ilişkin Aşamalı Regresyon Analizi sonuçları

\begin{tabular}{|c|c|c|c|c|c|c|}
\hline \multirow{2}{*}{ Model } & & \multicolumn{2}{|c|}{$\begin{array}{c}\text { Standardize olmayan } \\
\text { katsayılar }\end{array}$} & \multirow{2}{*}{$\begin{array}{c}\text { Standardize katsayılar } \\
\text { ß (Beta) }\end{array}$} & \multirow[t]{2}{*}{$t$} & \multirow[t]{2}{*}{$p$} \\
\hline & & $B$ & SE & & & \\
\hline \multirow{2}{*}{ Model 1} & Sabit & 90.064 & 2.577 & -.351 & 34.946 & .000 \\
\hline & Kaygı Düzeyi & -.346 & .104 & & -3.313 & .001 \\
\hline \multirow{3}{*}{ Model 2} & Sabit & 65.516 & 12.522 & & 5.232 & .000 \\
\hline & Kaygı Düzeyi & -.306 & .104 & -.311 & -2.935 & .004 \\
\hline & Akademik Güdülenme & .315 & .157 & .212 & 2.002 & .049 \\
\hline
\end{tabular}

Model 1: $R^{2}=.123 ; F=10.977 ; p=.001(p<.05)$

Model 2: $R^{2}=.167 ; F=7.703 ; p=.001(p<.05)$

Araştırmada ele alınan değişkenlerden; kaygı düzeyi ve akademik güdülenmenin bireysel çalgı başarısının anlamlı yordayıcıları oldukları ve bireysel çalgı puanındaki değişkenliğin yaklaşık \% 17 'sinin $\left(R^{2}=.167\right)$ bu iki değişkenle açıklanabileceği bulunmuştur.

\section{Sonuçlar}

Araştırma sonuçları, bireysel çalgı performans başarısını yordayıcılığı test edilen değişkenlerden; kaygı düzeyinin negatif yönde, akademik güdülenmenin ise pozitif yönde güçlü anlamlı yordayıcılar olduğunu yansıtmaktadır. Ancak çalgı geçmişi, denetim odağı gibi değişkenlerle bireysel çalgı başarısı arasındaki ilişkilerin istatistiksel olarak anlamlı olmadığı gözlenmiştir.

Bu araştırmanın, akademik güdülenmenin bireysel çalgı performans başarısının anlamlı bir yordayıcısı olduğu bulgusu literatürde güdülenmenin genel akademik başarının güçlü yordayıcısı olduğu bulgularıyla paralellik göstermektedir (Kapıkıran ve Özgüngör, 2009). Bu bulgu aynı zamanda Asmus'un (1995, akt. Schmidt ) müzik başarısı ve ilişkili özelliklerin yaklaşık \% 20'sinin güdülenme ile açıklandığı araştırma bulgusu ile kısmen örtüşmektedir. Öğrenen kişinin öğrenmeye yönelik istekliliği, çabası öğrenme sürecinde oldukça önemli etkenlerdir (Kelecioğlu, 1992; Demir ve Arı, 2013). Özellikle çalgı eğitimi alanında, performans gelişiminde öğrencinin pratik yapması çalgı eğitiminin önemli bir boyutudur. Bu araştırmada, günlük çalgı çalışma süresi her ne kadar çalgı başarısını yordayıcı bir değişken olarak bulun- 
masa da, bireysel çalgı başarısı ve akademik güdülenme ile ilişkili bir değişken olarak bulunmuştur. Bu bulgu güdülenme ile günlük çalışma süresi yani öğrencinin çaba göstermesi arasındaki bağlantryı yansıtması bakımından önemlidir. Sonuç olarak güdülenmenin çalgı performans başarısında önemli bir etken olduğu bu araştırma bulguları ile desteklenmektedir. İlgili literatürde güdülenmeyi etkileyen etkenleri, güdülenme kaynaklarını belirlemeye yönelik bazı çalışmalar bulunmaktadır. Ünlü (2013) lise öğrencileri ile yaptığı çalışmada kişiliğin ve sorumluluğun akademik güdülenmeyi en fazla etkileyen değişkenler olduğunu raporlaştırmıştır. Müzik eğitimi öğrencilerinde ise yeniliğe açıklık, dışa dönüklük gibi kişilik özelliklerinin daha fazla olduğu bulguları (Yöndem, Yöndem ve Per, 2017) bulunmaktadır. Müzik eğitimi öğrencilerinin yetenek sınavıyla ve genellikle istekli olarak geldikleri dikkate alındığında akademik güdülenme için uygun özellikler taşıdıklarını düşündürmektedir.

Müzik eğitimi öğrencilerinin lisans öğrenimi sürecinde, akademik ve performans güdülenmesini canlı tutacak, aktif hale getirecek birtakım yaklaşım ve uygulamalarla, güdülenmeleri ve çalgı performans başarıları artırılabilir. Örneğin; bireysel çalgı seçiminde yetenek ile birlikte isteklilik, gönüllülük ilkesinin dikkate alınması çalgı performans başarısı açısından önemli olabilir. Yine bireysel çalgı performansını sadece sınavlar ile değerlendirmek yerine, resital, konser, konser gezisi gibi uygulamalı etkinliklerle desteklemek öğrenci güdülenmesini artrabilir. Ayrıca araştırma literatüründe sıklıkla öz yeterlik inancı ile güdülenme ve başarı ilişkisi (Azar, 2010) vurgulanmaktadır. Bu bakımdan öğretim elemanı öğrenci etkileşiminde olumlu iletişim teknikleri kullanarak, öğrencilerin başarısından dolayı takdir edilmesi, onaylanması gibi güdülenmeyi olumlu yönde etkileyecek öğretim elemanı yaklaşımları da oldukça önemli etkenler olarak sıralanabilir.

Araştırmanın kaygı düzeyinin bireysel çalgı performansı başarısının anlamlı bir yordayıcısı olduğu bulgusu, müzik alanında sıklıkla çalışılan sahne kaygısı olarak da geçen performans kaygısı bulguları ile paralellik göstermektedir. Araştırma literatüründe, müzik performans kaygısının doğrudan çalgı performans başarııını yordayııılığını test eden benzer bir çalışmaya rastlanmamıştır. Ancak performans kaygısının müzik eğitimi öğrencilerini de kapsayan, amatör ya da profesyonel farklı gruplarda yaygın olarak gözlendiği ve müzisyenlerin mesleki kariyerini olumsuz yönde etkilediği bulguları bulunmaktadır (Yöndem, 2012).

Bu araştırmadan elde edilen, kaygının güçlü bir yordayıcı olduğu bulgusu, çalgı performans başarısı puanlarının komisyon üyelerinin çalgı performansını değerlendirdiği sınav puanlarının alınmasından kaynaklanabileceği dikkate alınmalıdır. Mükemmelliyetçi, genel olarak kaygılı kişilik yapısı ya da yetersiz çalgı pratiğinden kaynaklanabilen çalgı performans kaygısı, çalgı eğitimi veren öğretim elemanlarının aşırı eleştirel ya da benzeri uygun olmayan yaklaşımlarından da kaynaklanabilmektedir. Bu nedenle güdülenme ile ilgili tartışmada vurgulandığı gibi yıpratıcı olmaktan çok yapıcı ve besleyici geri bildirimler veren, takdir eden, cesaretlendiren öğretim elemanı yaklaşımları çalgı performans başarısı açısından kaygıyı azaltıcı güdülenmeyi artırıcı yaklaşımlar olarak önerilebilir.

Araştırmada, çalgı geçmişi ve denetim odağı, çalgı performans başarısı ile ilişkili bulunmamıştı. Çalgı geçmişinin, çalgı performans başarısı ile ilişkili bulunmaması, genellikle profesyonel eğitim alınmadan ilerleyen çalgı geçmişinin çalgı performans başarısında pek fazla etkili olmadığını düşündürmektedir. Oysa okullarda müzik eğitimi kapsamında, müzik eğiticilerinin rehberliği ile erken yaşlarda çalgı eğitimlerinin başlatılması, çalgı performansının olumlu yönde gelişmesini ve dolayısıyla başarıyı etkileyebilir.

Son olarak araştırmanın, denetim odağının, çalgı performans başarısı ile ilişkili olmadığı bulgusu, Austin (1988, akt. Schmidt, 2005)'in ilkokul müzik grubunda performans sergileyen çocuklarla yaptı̆̆ı, içsel ya da dışsal denetimin müzik başarısı ile ilişkili olmadığı bulgusu ile paralellik göstermektedir. Benzer şekilde Miksza (2006) lise öğrencileriyle yaptığı araştırmada denetim odağının müzik performans başarısını yordayıcı bir özellik olmadığını raporlaştırmıştır. Ancak müzik performansı literatüründe başarı ya da başarısızlığı yetenek, çaba gibi içsel etkenlere yüklemenin önemi (Austin ve Vispoel, 1992; 1998) ve çabaya yüklemenin günlük çalgı çalışma süresi ile ilişkili olduğu vurgulamaları da bulunmaktadır (Schmidt, 2005). Müzik eğitimi öğrencilerinin daha içsel denetim odaklı oldukları bulgusu (Akbulut, 2006) ve genellikle şans, şanssızık gibi yüklemeler yerine, yetenek ve çabanın çalgı performansı alanında yaygın olarak kabul görmesi araştırma bulgularını desteklemektedir. Ancak bu araştırmanın denetim odağının akademik güdülenme ile ilişkili olduğu bulgusu göz önünde bulundurularak, müzik eğitimi öğrencilerinin yükleme stillerinin ve başarı ya da başarısızlığa ilişkin inançlarının farklı araştırmalarla yeniden test edilmesi yararlı olacaktır.

\section{5. Öneriler}

Ön Araştırma sonuçlarının yorumlanmasında; katılımcı sayısının kısmen düşüklüğü, günlük çalışma süresinin katılımcıların kendi bildirimine dayalı olarak belirlendiği ve komisyon değerlendirmesine dayalı bireysel çalgı puanının kaygı ile ilişkiye yansımış olabileceği gibi sınırıııkları göz önünde bulundurulmalıdır. 


\section{Kaynakça}

Akbulut, E. (2006). Müzik eğitimi anabilim dalı öğrencilerinin denetim odaklarına ilişkin algıları. Gazi Üniversitesi Gazi Eğitim Fakültesi Dergisi, 26(3):171-180.

Aksu, C. ve Çelenk, K. (2014). Anadolu güzel sanatlar ve spor lisesi müzik bölümü mezunlarının güzel sanatlar fakülteleri müzik bölümlerindeki akademik başarılarının incelenmesi. Electronic Turkish Studies .9(2):67-87.

Austin J. R., \& Vispoel, W. P. (1998). How american adolescents interpret success and failure in classroom music: relationships among attributional beliefs, self concepts and achievement. Psychology of Music,26:26-45.

Austin, J.R. ve Vispoel, W.P.(1992) Motivation after failure in school music performance classes: the facilitative effects of strategy attributions. Bulletin of the Council for Research in Music Education, 111: 1-23.

Azar, A. (2010). Ortaöğretim fen bilimleri ve matematik öğretmeni adaylarının öz yeterlilik inançları. Zonguldak Karaelmas Üniversitesi Sosyal Bilimler Dergisi, 6(12): 235-252.

Bozanoğlu, i. (2004). Akademik güdülenme ölçeği: geliştirilmesi, geçerliği, güvenirliği (Academic Motivation Scale: Development, Reliability, Validity). Ankara Üniversitesi Eğitim Bilimleri Fakültesi Dergisi, 37(2): 83-98.

Cribb,C., Gregory,A.H.(1999). Streotypes and personalities of musicians, The Journal of Phychology, 133(1): 104-114.

Demir, M. K. ve Arı, E. (2013). Öğretmen adaylarının akademik güdülenme düzeylerinin çeşitli değişkenler açısından incelenmesi, Eğitimde Kuram ve Uygulama, 9(3):265-279.

Deryakulu, D. (2002). Denetim odağı ve epistemolojik inançların öğretim materyalini kavramayı denetleme türü ve düzeyi ile ilişkisi. Hacettepe Üniversitesi Eğitim Fakültesi Dergisi, (22):55-61.

Dönmez, A. (1985). Denetim odağı, kendine saygı ve üç değişken “çevre büyüklüğü, yaş, aile ortamı”. Eğitim ve Bilim, 10(55):4-15.

Güleç, K. S. (2009). Müziğin kişisel işlevleri açısından müzik eğitiminde güdülenmenin önemi. Uluslararası Asya ve Kuzey Afrika Çalışmaları Kongresi-ICANAS 38, Müzik Kültürü ve Eğitimi, Atatürk Kültür, Dil ve Tarih Yüksek Kurumu Yayınları, 1(1):365-375.

Kapıkıran, Ş. ve Özgüngör, S. (2009). Ergenlerin sosyal destek düzeylerinin akademik başarı ve güdülenme düzeyi ile ilişkisi. Çocuk ve Gençlik Ruh Sağlığı Dergisi,16(1):21-30.

Kelecioğlu, H. (1992). Güdülenme. Hacettepe Üniversitesi Eğitim Fakültesi Dergisi, 7: 175-181.

Klinedinst, R.E. (1991). Predicting performance achievement and retention of fifth-grade instrumental students. Journal of Research in Music Education, 39(3): 225-238.

Kurtuldu, M.K. ve Aksu, C. (2016). Müzik öğretmeni adaylarının lisans programı başarılarının mezun olunan lise türüne göre karşılaştıılması. Electronic Turkish Studies, 11(14):425-440.

Küçük, D. P. (2010). Müzik öğretmeni adaylarının sınav kaygısı, benlik saygısı ve çalgı başarıları arasındaki ilişkinin incelenmesi. Ahi Evran Üniversitesi Eğitim Fakültesi Dergisi, 11(3): 37-50.

McPherson,G.E.\&McCormick,J.(2006). Self-efficacy and music performance. Psychology of Music, 34 (3):325-339.

Miksza, P. (2006). Relationships among ımpulsiveness, locus of control, sex, and music practice. Journal of Research in Music Education, 54(4): 308-323.

Modırı, I. G. (2012). Müzik öğretmenliği öğrencilerinin piyano dersi motivasyonları ile kişilik özellikleri arasındaki ilişki. Yüzüncü Yıl Üniversitesi Eğitim Fakültesi Dergisi, 9(1):74-98.

Nacakcı, Z., ve Dalkıran, E. (2011). Müzik eğitimi anabilim dalı öğrencilerinin bireysel çalgı sınavına yönelik kaygıları. Mehmet Akif Ersoy Üniversitesi Sosyal Bilimler Enstitüsü Dergisi, 3(5):46-56.

Onuk, Ö. (2007). Müzik öğretmenliği lisans programı öğrencilerinin öğretmenliğe güdülenmeleri ile akademik başarıları arasındaki ilişki. Yayımlanmamış Doktora Tezi, Gazi Üniversitesi, Ankara.

Orhan, Ş. (2010). Anadolu güzel sanatlar liseleri çalgı eğitiminde motivasyon. Buca Eğitim Fakültesi Dergisi, (20): 130-136.

Özmenteş, S. (2013). Çalgı eğitiminde öğrenci motivasyonu ve performans. Ĕgitim ve Öğretim Araştırmaları Dergisi, 2(2): $320-331$.

Özmenteş, S. ve Özmenteş, G. (2009). Çalgı çalışmaya ilişkin tutum, bireysel özellikler ve performans düzeyi ilişkileri. Kastamonu Eğitim Dergisi,17(1): 353-360.

Savaşır, I. ve Şahin N. H. (1997). Bilişsel davranışçı terapilerde değerlendirme: sık kullanılan ölçekler. Ankara: Türk Psikologlar Derneği Yayınları.

Schmidt, C.P. (2005). Relations among motivation, performance achievement, and music experience variables in secondary ınstrumental music students. Journal of Research in Music Education, 53(2): 134-147.

Sloboda, J.A. (2000). Individual differences in music performance. Trends in Cognitive Sciences, 4: 397-403.

Slavin, R.E. (2012). Eğitim psikolojisi kuram ve uygulama (Çev.Ed.G.Yüksel).Ankara: Nobel Yayınevi.

Şahin, H. ve Çakar, E. (2011). Eğitim fakültesi öğrencilerinin öğrenme stratejileri ve akademik güdülenme düzeylerinin akademik başarılarına etkisi. Türk Eğitim Bilimleri Dergisi, 9(3): 519-540.

Ünlü, M. (2013). Lise öğrencilerinin akademik güdülenme düzeylerinin bazı değişkenler açısından yordanması. Yayımlanmamış Yüksek Lisans Tezi. İzmir: Dokuz Eylül Üniversitesi. 
Yağışan, N., Sünbül A. M. ve Yücalan Ö. B. (2007). Müzik bölümü öğrencilerinin benlik imgeleri ve denetim odaklarının incelenmesi. Erciyes Üniversitesi Sosyal Bilimler Enstitüsü Dergisi, (22): 243-262.

Yöndem, Z. D. (2012). Müzik öğrencilerinde algılanan performans kaygısının fiziksel, davranışsal ve bilişsel özellikleri: nitel bir çalışma. Eğitim ve Bilim, 37(166): 181-194.

Yöndem, S. (2016). Müzik eğitiminde çalgı topluluklarının önemi ve işleyişi, Abant İzzet Baysal Üniversitesi Eğitim Fakültesi Dergisi, 16 (ipekyolu Özel Sayısı), 2568-2579.

Yöndem, S., Yöndem, D. Z., ve Per, M. (2017). Personality traits and psychological symptoms of music and art students. Journal of Education and Training Studies,5(7):53-59. 